\title{
EKSISTENSI MADRASAH DINIYYAH TAKMILIYYAH AWWALIYAH (MDTA) AL-AMIN DALAM MENANAMKAN NILAI-NILAI PENDIDIKAN ISLAM DI KALANGAN SISWA MINORITAS MUSLIM DI DESA LAU BEKERI KECAMATAN KUTALIMBARU DELI SERDANG
}

\author{
Oleh: Sofyan \\ STAI Darul Arafah Deli Serdang \\ sofyanma543@gmail.com
}

\begin{abstract}
Abstrak
Penelitian ini bertujuan untuk membahas sejarah berdirinya MDTA Al-Amin, nilai-nilai Pendidikan Islam yang diajarkan, metode penanaman nilai-nilai pendidikan Islam serta hambatan dalam menanamkan nilainilai pendidikan Islam dikalangan siswa yang minoritas Muslim di Desa Lau Bekeri Kutalimbaru Deli Serdang. Penulis menggunakan penelitian kulitatif deskriptif dengan pendekatan field research (penelitian lapangan). Sebagai key instrumen penulis terjun langsung ke lapangan untuk mengumpulkan data dari sumber primer dan sekunder yang diperoleh melalui wawancara, observasi dan studi dokumentasi. Data dianalisis menurut pemikiran Miles dan Huberman. Untuk menjamin keabsahan data digunakan triangulasi dan perpanjangan penelitian. Hasil penelitian menjelaskan MDTA Al-Amin berdiri atas saran dari BKM Masjid Al-Amin yang menginginkan anak-anak di tingkat dasar dibekali dengan pemahaman agama Islam agar menjadi generasi tangguh, yang saleh serta salehah dan siap menghadapi lingkungan yang mayoritas non Muslim. Nilai-Nilai Pendidikan Islam yang diajarkan meliputi akidah dan akhlak, Alquran, Bahasa Arab, sejarah Islam, tafsir, hadis, fikih, tambahan aksara Arab Melayu, al-khat (menulis indah). Metode yang dipergunakan ceramah, demonstrasi, dan training. MDTA Al-Amin mendapat dukungan dana dari Pemerintah Kabupaten Deli Serdang untuk honor pendidik, dukungan dana dari donatur yang tidak terikat, dan masyarakat di sekitar Desa Lau Bekeri. Hambatan dalam menanamkan pendidikan Islam meliputi pemahaman orang tua yang minim terhadap agama sehingga kurang mendorong anak untuk belajar agama, hambatan teknologi dalam hal ini media sosial, serta lingkungan pergaulan yang mayoritas non Muslim dimana mereka tidak beribadah sesuai tuntunan Islam sehingga anak-anak Muslim pun takut ikut terpengaruh dengan pergaulan mereka. Bahkan yang Muslim sendiri pun masih banyak yang tidak menjalankan ajaran Islam dengan baik.

Kata Kunci : Madrasah Diniyah, Pendidikan Islam, Al-Amin
\end{abstract}

\section{PENDAHULUAN}

Menumbuhkan kecintaan terhadap Allah, Rasul dan agama Islam sangat urgen bagi setiap Muslim. Penanaman nilai-nilai pendidikan Islam dan ilmu-ilmu keagamaan sejatinya dilakukan ketika masih anak-anak karena konsep keagamaan pada anak mengikuti pola ideas concept on outhority yaitu pola dimana ide keagamaan pada diri anak dipengaruhi oleh faktor dari luar diri

Al-Madrasah: Jurnal Ilmiah Pendidikan Madrasah Ibtidaiyah

Vol. 6, No. 1, Januari-Maret 2022 
Sofyan : Eksistensi Madrasah Diniyyah Takmiliyyah Awwaliyah (MDTA) Al-Amin Dalam Menanamkan Nilai-Nilai Pendidikan Islam di Kalangan Siswa Minoritas Muslim di Desa Lau Bekeri Kecamatan Kutalimbaru Deli Serdang

mereka seperti dari orang tua maupun orang-orang dewasa. ${ }^{1}$

Sejak kecil anak-anak melihat dan mempelajari hal-hal yang berada di luar diri mereka tentang berbagai hal termasuk di dalamnya yang berkaitan dengan agama. Mereka melihat dan mengikuti apa yang dilakukan dan diajarkan oleh orang dewasa, baik guru maupun orang tua pada saat menanamkan ajaran agama baik di rumah maupun di lembaga pendidikan. Ketaatan anak pada ajaran agama merupakan kebiasaan yang menjadi milik mereka, yang mereka pelajari dan mereka laksanakan atas perintah dari para guru maupun orang tua. ${ }^{2}$

Menurut Lahmuddin Lubis penanaman agama kepada anak sejak kecil sangat penting karena anak yang tidak memperoleh didikan agama dan pengalaman keagamaan sewaktu kecil maka setelah dewasa ia cenderung acuh tak acuh terhadap agama bahkan memiliki pandangan dan sikap yang negatif terhadap agama. ${ }^{3}$

Sejak kecil anak-anak harus dibiasakan melaksanakan ajaran Islam dengan cara menanamkan, membekali anak dengan ilmu-ilmu keislaman baik dimulai dari rumah maupun di lembaga-lembaga pendidikan Islam. Dalam hal ini madrasah menjadi salah satu lembaga keislaman yang berperan penting untuk mengembangkan wawasan pengetahuan agama peserta didik.

Eksistensi madrasah sudah diatur di dalam Undang-Undang Sistem Pendidikan Nasional Bab VI, Jalur, Jenjang dan Jenis Pendidikan Bagian Kedua Pasal 17 ayat 2 untuk tingkat dasar Madrasah Ibtidaiyah (MI), dan Madrasah Tsanawiyah (MTs), Pasal 18 ayat 3 untuk tingkat menengah Madrasah Aliyah (MA) dan bagian keempat pasal 19 mengatur tentang pendidikan tinggi. ${ }^{4}$

Di dalam pasal 30 Undang-Undang Sistem Pendidikan Nasional menjelaskan tentang pendidikan keagamaan. Pada ayat 1 dijelaskan penyelenggara pendidikan agama dapat dilaksanakan oleh pemerintah atau kelompok masyarakat dari pemeluk agama, sesuai peraturan perundang-undangan dan pasal 2 menjelaskan bahwa pendidikan keagamaan berfungsi untuk mempersiapkan peserta didik menjadi anggota masyarakat yang memahami dan mengamalkan nilai-nilai ajaran agamanya. ${ }^{5}$

${ }^{1}$ Jalaluddin, Psikologi Agama (Jakarta: Rajawali Pers, 2012), h. 70.

${ }^{2}$ Ibid.,

${ }^{3}$ Lahmuddin Lubis dan Elfiah Muchtar, Pendidikan Agama Dalam perspektif Islam, Kristen dan Budha (Bandung: Citapustaka Media Perintis, 2013), h. 12.

${ }^{4}$ Suparta, Undang-Undang dan Peraaturan Pemerintah RI Tentang Pendidikan (Jakarta: Direktorat Jenderal Pendidikan Islam Departemen Agama RI, 2006), h. 13-15.

${ }^{5}$ Ibid, h. 21.

Al-Madrasah: Jurnal Ilmiah Pendidikan Madrasah Ibtidaiyah Vol. 6, No. 1, Januari-Maret 2022 
Sofyan : Eksistensi Madrasah Diniyyah Takmiliyyah Awwaliyah (MDTA) Al-Amin Dalam Menanamkan Nilai-Nilai Pendidikan Islam di Kalangan Siswa Minoritas Muslim di Desa Lau Bekeri Kecamatan Kutalimbaru Deli Serdang

Berdasarkan undang-undang di atas eksistensi madrasah sebagai lembaga pendidikan keagamaan memiliki legalitas kuat, yang diakui negara. Dengan berdirinya madrasah diharapkan dapat memberikan manfaat bagi masyarakat Muslim untuk menanamkan ajaran agama Islam sejak dini agar mereka dapat memahami, mematuhi, melaksanakan perintah dan menjauhi larangan Tuhan sejak masih anak-anak.

Lembaga pendidikan Islam di tingkat dasar ada Madrasah Ibtidaiyah (MI) atau Madrasah Diniyyah Takmiliyah Awwaliyah (MDTA). Kedua lembaga ini memiliki peran sentral dalam mengembangakan pendidikan di kalangan generasi muda Muslim. Salah satu lembaga pendidikan Islam yang menjadi fokus dalam tulisan ini adalah Madrasah Diniyah Takmiliyyah Awwaliyah (MDTA) Al-Amin yang berada di Desa Lau Bekeri Kecamatan Kutalimbaru Deli Serdang Sumatera Utara.

MDTA Al-Amin merupakan lembaga keagamaan yang didirikan oleh sekelompok masyarakat minoritas Muslim yang peduli dengan pendidikan agama anak. Mereka bergotong royong untuk mengumpulkan biaya dan tenaga mendirikan madrasah ini. Ilmu-ilmu keislaman yang diajarkan di MDTA Al-Amin berdasarkan silabus antara lain ilmu fikih, hadis, akidah akhlak, bahasa Arab, aksara Arab Melayu, menulis indah (al-khat), sejarah Islam (Tarikh), tajwid dan lain-lain. ${ }^{6}$ Ilmu-ilmu ini penting diajarkan kepada anak-anak Muslim untuk melindungi akidah dari kemungkinan terkontaminasi dengan lingkungan yang mayoritas non Muslim dan menjaga ibadah dari berbagai dinamika gelombang kehidupan yang dapat melalaikan manusia mengingat Allah swt.

Menurut Ustaz Abidin Saragih MDTA Al-Amin berdiri di Desa Lau Bekeri yang memiliki IX dusun terdiri dari berbagai macam etnis dan suku, seperti Suku Jawa, Mandailing, Padang, Nias, Batak atau Karo. Mayoritas masyarakat di desa ini sekitar $65 \%$ adalah Suku Batak atau Karo yang beragama non Muslim, dan sisanya 35\% beragama Islam. Di MDTA Al-Amin inilah anak-anak Muslim yang berada di tingkat sekolah dasar belajar dan mendalami ilmu-ilmu agama Islam. Para orang tua berharap pendidikan di MDTA Al-Amin mampu menguatkan pemahaman agama anak sehingga penanaman nilai-nilai agama harus tertanam kuat agar generasi muda tidak mudah berpaling kepada agama lain. ${ }^{7}$

Dengan ilmu-ilmu keislaman yang telah tertanam dalam diri anak-anak Muslim tentu menjadi bekal bagi mereka untuk membiasakan diri untuk mengimplementasikan ajaran Islam

\footnotetext{
${ }^{6}$ Hasil observasi dan studi dokumentasi Buku Silabus dan Kurikulum Pendidikan dan Pengajaran di MDTA Syuhada.

${ }^{7}$ Wawancara dengan Ustaz Abidin Saragih, Kepala Sekolah MDTA Syuhada
}

Al-Madrasah: Jurnal Ilmiah Pendidikan Madrasah Ibtidaiyah

Vol. 6, No. 1, Januari-Maret 2022 
Sofyan : Eksistensi Madrasah Diniyyah Takmiliyyah Awwaliyah (MDTA) Al-Amin Dalam Menanamkan Nilai-Nilai Pendidikan Islam di Kalangan Siswa Minoritas Muslim di Desa Lau Bekeri Kecamatan Kutalimbaru Deli Serdang

dalam kehidupan sehari-hari sehingga mereka kelak tumbuh menjadi generasi muda yang kuat iman dan taqwanya kepada Allh swt, menjadi hamba Tuhan yang berakhlak karimah, saleh secara individual maupun saleh secara sosial. ${ }^{8}$

Pendidikan di MDTA Al-Amin dilaksanakan sore hari setelah pulang dari sekolah dari pukul 14.30 WIB sampai 17.00 WIB. Pendidikan di MDTA ini mengajarkan dan menanamkan kepada mereka ilmu-ilmu keislaman yang berguna untuk memahami dan mengetahui tata cara beribadah yang baik dan benar seperti berwudhu, shalat 5 waktu, berbakti kepada orang tua, menghormati guru, menghargai sesama manusia, zakat, berhaji. Mereka juga belajar Alquran, sejarah Islam dan akidah. ${ }^{9}$

Ustaz Abidin Saragih menjelaskan bahwa anak-anak Muslim yang berada di lingkungan Desa Lau Bekeri banyak yang belajar di MDTA Al-Amin tetapi masih banyak juga yang enggan belajar. Masih banyak anak-anak muslim yang tidak dididik dengan dasar-dasar agama. Diantara penyebabnya ekonomi orang tua lemah, dengan alasan tidak memiliki biaya sehingga tidak memasukkan anaknya belajar agama, pemahaman agama yang minim, teknologi berbasis media sosial semakin menancapkan kukunya di kalangan generasi muda, sehingga mereka lebih banyak menghabiskan waktunya di depan media sosial ditambah lagi kondisi lingkungan yang kurang mendukung karena berada di antara warga yang beda akidah. ${ }^{10}$

Inilah dinamika dan tantangan yang dihadapi oleh umat Islam khususnya di Desa Lau Bekeri Kecamatan Kutalimbaru Deli Serdang. Walaupun berada di lingkungan masyarakat non Muslim namun sikap saling menghargai, menghormati dijunjung tinggi. Adat lebih utama di sini dari dogma agama.

Untuk mengetahui eksistensi MDTA Al-Amin dalam menanamkan nilai-nilai pendidikan Islam di kalangan siswa minoritas Muslim maka tulisan ini menguraikan hal-hal yang berkaitan dengan sejarah berdirinya MDTA Al-Amin, kurikulum pembelajaran untuk menguatkan nilainilai pendidikan Islam di tengah-tengah masyarakat Muslim minoritas di Desa Lau Bekeri Kecamatan Kutalimbaru, kendala yang menghambat dan faktor yang mendukung keberadaan MDTA Al-Amin.

\footnotetext{
${ }^{8}$ Ibid.,

${ }^{9}$ Ibid.,

${ }^{10}$ Ibid.,
}

Al-Madrasah: Jurnal Ilmiah Pendidikan Madrasah Ibtidaiyah

Vol. 6, No. 1, Januari-Maret 2022 
Sofyan : Eksistensi Madrasah Diniyyah Takmiliyyah Awwaliyah (MDTA) Al-Amin Dalam Menanamkan Nilai-Nilai Pendidikan Islam di Kalangan Siswa Minoritas Muslim di Desa Lau Bekeri Kecamatan Kutalimbaru Deli Serdang

\section{METODE PENELITIAN}

Penelitian ini termasuk jenis penelitian kulitatif deskriptif interaktif dengan pendekatan field research (penelitian lapangan). Penulis sebagai key instrumen terjun langsung ke lokasi penelitian di MDTA Al-Amin untuk mengumpulkan data penelitian dari sumber primer diantaranya Kepala Sekolah MDTA Al-Amin, tenaga pendidik, tokoh masyarakat, buku dan kurikulum pembelajaran di MDTA.

Data-data tersebut diperoleh dan dikumpulkan melalui 3 cara wawancara, observasi dan studi dokumentasi. Setelah data diperoleh kemudian dianalisis melalui analisis menurut Miles dan Huberman melalui empat cara reduksi data, penyajian data, verifikasi serta kesimpulan. Untuk menjamin keabsahan data digunakan triangulasi dan perpanjangan penelitian.

\section{HASIL PENELITIAN DAN PEMBAHASAN}

\section{Deskripsi Umum MDTA Al-Amin}

\section{a. Sejarah Berdirinya Madrasah Diniyah Takmiliyyah Awwaliyah (MDTA) Al-Amin}

Berdirinya MDTA Al-Amin tidak bisa terlepas dari keberadaan Masjid Syuhada yang lokasinya di pinggir Jl. Berdikari Desa Lau Bekeri Kecamatan Kutalimbaru Kabupaten Deli Serdang. Berdirinya masjid ini untuk memenuhi kebutuhan umat Islam minoritas dalam rangka menjalin hubungan yang baik secara vertikal dengan sang Khalik Allah swt. serta wadah menjalin silaturrahmi melalui shalat lima waktu, shalat Jum'at maupun pengajian-pengajian yang dilaksanakan oleh masyarakat Muslim di Desa Lau Bekeri yang majemuk, terdiri dari berbagai macam suku, baik Suku Jawa, Mandailing, Minang, Batak serta minoritas Muslim Karo. Walaupun berada di mayoritas masyarakat Suku Karo yang beragama non Muslim kehidupan masyarakat berjalan dengan damai, saling memahami dan menghargai perbedaan.

MDTA Al-Amin posisinya berada di dalam kompleks Masjid Syuhada. Berdirinya MDTA ini tidak terlepas dari peran pengurus Badan Kenaziran Masjid (BKM) Syuhada terutama bidang pendidikan dimana mereka memiliki gagasan dan program kerja untuk mendirikan lembaga pendidikan Islam tingkat dasar MDTA. Tujuan didirikannya untuk mendidik dan mempersiapkan generasi muda Muslim menguasai dasar-dasar ilmu agama Islam agar mereka memiliki akidah yang kuat, baik akhlak dan ibadahnya. Lingkungan yang mayoritas non Muslim menjadi alasan kuat agar anak-anak mendapatkan pendidikan agama yang memadai, ditambah lagi pelajaran agama di sekolah dirasakan sangat kurang, hanya dua jam dalam satu minggu.

Untuk mendirikan madrasah ini bukanlah perkara mudah, banyak tantangannya. Dengan izin Allah swt. serta doa dan dukungan masyarakat di sekitar Desa Lau Bekeri pada tahun 2000

\section{Al-Madrasah: Jurnal Ilmiah Pendidikan Madrasah Ibtidaiyah}

Vol. 6, No. 1, Januari-Maret 2022 
Sofyan : Eksistensi Madrasah Diniyyah Takmiliyyah Awwaliyah (MDTA) Al-Amin Dalam Menanamkan Nilai-Nilai Pendidikan Islam di Kalangan Siswa Minoritas Muslim di Desa Lau Bekeri Kecamatan Kutalimbaru Deli Serdang

kegiatan belajar mengajar dan pengajian non formal dilaksanakan dalam Masjid Al-Amin. Karena kurangnya finansial dan dukungan dana dari masyarakat minoritas Muslim kegiatan pengajian tidak dilaksanakan dalam gedung. Semua aktivitas pembelajaran dilakukan sekitar masjid. Seiring dengan perjalanan waktu setelah 5 tahun kegiatan pendidikan berjalan tepatnya pada tahun 2005 berdirilah 1 kelas Madrasah Al-Amin. Kemudian 3 tahun berikutnya yaitu tahun 2008 sarana belajar ditambah 1 kelas lagi dan tahun 2013 ditambah lagi dua kelas menjadi 4 kelas. Pembangunan kelas di Madrasah Al-Amin pun terasa lamban karena minimnya dukungan dana. Secara bertahab-tahab dengan semangat gotong royong di kalangan umat Islam sedikit demi sedikit ruang belajar pun dapat ditambah. ${ }^{11}$

Kendati sarana dan prasarana sangat terbatas namun kegiatan pengajian dan pendidikan tetap berjalan dengan baik. Mereka tetap mengikuti program-program pembelajaran sebagaimana yang dilaksanakan oleh MDTA-MDTA pada umumnya, kegiatan pembelajaran di kelas, ekstra kurikuler maupun ujian-ujian yang harus diselesaikan di setiap jenjang kelas dilaksanakan dengan baik mengingat madrasah ini sudah terdaftar di Kementrian Agama Deli Serdang sejak tahun 2008 dengan nomor Statistik MDTA 311212070003. Pada tahun 2017 Madrasah Al-Amin mendapatkan piagam pengakuan dengan nomor piagam B.970/Kk.02.01/3/PP.07/04/2017 dari Kementrian Agama Deli Serdang untuk melaksanakan proses pendidikan dan pengajaran. Sejak dikeluarkannya piagam tersebut proses pendidikan dan pengajaran di MDTA Al-Amin sudah diakui dan terdaftar, sehingga kepala sekolah ustaz Abidin Saragih pun mulai menata dan mengelola Madrasah Al-Amin. ${ }^{12}$

Hal-hal yang beliau lakukan untuk meningkatkan kualitas pendidikan dan pengajaran antara lain melengkapi sarana dan prasarana pendidikan dengan menyiapkan kelas sebagai wadah untuk belajar. Saat ini sudah ada empat kelas, ditambah dengan satu kantor guru dengan empat orang guru dan satu kepala sekolah. Kemudian mencari guru-guru tamatan pesantren yang sudah sarjana S1 dan mampu berbahasa Arab, karena materi yang akan diajarkan menggunakan bahasa Arab seperti akidah, akhlak, Alquran, fikih, Hadis, bahasa Arab, Sejarah Kebudayaan Islam. ${ }^{13}$ Dengan memiliki guru-guru dari latarbelakang alumni pesantren yang mahir bahasa Arab maka siswa dapat belajar bahasa Arab dengn baik .

Kegiatan pembelajaran dimulai dari jam 14.30 sampai 17.00 WIB, metode pembelajaran yang digunakan guru bervariasi, ada metode ceramah, demonstrasi dan pembiasaan. Siswa yang

\footnotetext{
${ }^{11}$ Abidin Saragih, Kepala Sekolah MDTA Al-Amin, wawancara di Perumahan Bumi Tuntungan Sejahtera.

${ }^{12}$ Studi dokumentasi Piagam dari Kementrian Agama Tingkat II Kabupaten Deli Serdang

${ }^{13}$ Studi dokumentasi Buku Silabus dan Kurikulum Pendidikan dan Pengajaran di MDTA Al-Amin.
} 
Sofyan : Eksistensi Madrasah Diniyyah Takmiliyyah Awwaliyah (MDTA) Al-Amin Dalam Menanamkan Nilai-Nilai Pendidikan Islam di Kalangan Siswa Minoritas Muslim di Desa Lau Bekeri Kecamatan Kutalimbaru Deli Serdang

belajar di MDTA Al-Amin saat ini berjumlah 70 orang, ada yang duduk di kelas 1 SD sampai kelas VI, dengan uang SPP Rp 15.000/bulan. Satu bulan biaya dari anak-anak terkumpullah Rp 1.050.000 dibagi empat guru. Selain itu setiap guru mendapatkan dana tambahan dari APBD Pemerintah Kabupaten Deli Serdang Rp 1.200.000/bulan. Kegiatan ekstra kurikuler di antaranya rihlah setiap akhir semester, latihan menulis kaligrafi, belajar pidato. Anak-anak dibiasakan untuk melaksanakan shalat Asar berjamaah, menyalami guru ketika masuk dan keluar dari kelas. Kegiatan pembelajaran di MDTA Al-Amin diakhiri dengan membaca do'a belajar kemudian shalat Asar berjamaah. ${ }^{14}$

\section{Kurikulum dan Nilai-Nilai Pendidikan Islam yang Diajarkan di MDTA Al-Amin}

Kurikulum menurut Omar Mohammad al-Toumy al-Syaibany dalam bukunya Falsafah al-Tarbiyah al-Islamiyah kurikulum menurut Islam disebut "Manhaj” artinya jalan terang yang dilalui oleh pendidik bersama anak didiknya untuk mengembangkan pengetahuan, ketrampilan dan sikap mereka. ${ }^{15}$

Dalam Kamus Umum Bahasa Indonesia disebutkan bahwa kurikulum merupakan susunan rencana pelajaran. ${ }^{16}$ Jadi kurikulum merupakan susunan rencana pelajaran yang dilakukan untuk mengembangkan pengetahuan, keterampilan dan sikap peserta didik.

Adapun materi pelajaran (kurikulum) yang ditanamkan kepada peserta didik di MDTA Syuhada terdiri dari berbagai ilmu keislaman, seperti ilmu fikih, hadis, akidah akhlak, bahasa Arab, aksara Arab Melayu, menulis indah (al-khat), sejarah Islam (Tarikh), Alquran dan tajwid.

a. Fikih

Ajaran Islam terdiri dari tiga hal pokok yaitu syariah, akidah dan akhlak. Syariah berkaitan dengan peraturan Allah yang mengatur hubungan antara manusia dengan Tuhan (ibadah), hubungan antara sesama manusia dan alam semesta (muamalah). Peraturan yang datangnya dari Allah, mengatur hubungan antara manusia dengan Tuhan disebut dengan ibadah. ${ }^{17}$

Materi fikih mengkaji permasalahan hukum yang berkaitan dengan berbagai aspek yang dijalani manusia dalam kehidupan baik secara pribadi, bermasyarakat maupun kehidupan yang mengatur antara manusia dengan manusia atau manusia dengan Tuhannya. Secara makna fikih diartikan dengan al-fahm (pemahaman), dimana peserta didik diwajibkan untuk memahami bagaimana cara-cara beribadah yang baik dan benar, dididik menjadi abd (hamba) Allah yang

\footnotetext{
${ }^{14}$ Hasil Observasi di MDTA Al-Amin

${ }^{15}$ Omar Mohammad al-Toumy al-Syaibany, Falsafah at-Tarbiyah al-Islamiyah, terj. Hasan Langgulung, Falsafah Pendidikan Islam (Jakarta: Bulan Bintang, 1979), h. 478.

${ }^{16}$ W.J.S. Poerwardarminta, Kamus Umum Bahasa Indonesia (Jakarta: Balai Pustaka, 1976), h. 543.

${ }^{17}$ Lubis dan Muchtar, Pendidikan Agama, h. 95.
}

Al-Madrasah: Jurnal Ilmiah Pendidikan Madrasah Ibtidaiyah

Vol. 6, No. 1, Januari-Maret 2022 
Sofyan : Eksistensi Madrasah Diniyyah Takmiliyyah Awwaliyah (MDTA) Al-Amin Dalam Menanamkan Nilai-Nilai Pendidikan Islam di Kalangan Siswa Minoritas Muslim di Desa Lau Bekeri Kecamatan Kutalimbaru Deli Serdang

taat dan saleh. Untuk itu mereka diajari tentang rukun, syarat sahnya wudhu, yang membatalkan dan tata cara berwudhu yang baik dan benar. Mereka juga diajari rukun, yang membatalkan tayamum, syarat tayamum dan cara bertayamum, begitu juga dengan ibadah-ibadah yang lain seperti cara melaksanakan shalat, umrah, maupun haji. ${ }^{18}$

Setiap hari peserta didik di MDTA Al-Amin melaksanakan shalat 'Asar berjamaah, ini untuk membiasakan dan melatih mereka tidak meninggalkan shalat, amalan yang kelak akan dihisab pertama sekali oleh Allah swt.

b. Hadis

Hadis menurut ulama ahli Hadis yaitu segala sesuatu yang disandarkan kepada Nabi saw. berkaitan dengan perkataan, perbuatan maupun taqrir. ${ }^{19}$ Sebagai sumber keilmuan kedua setelah Alquran maka pelajaran Hadis menjadi pelajaran yang wajib dipelajari di MDTA Al-Amin. Materi yang diajarkan diantaranya tentang akhlak, perintah shalat dan shalat berjamaah di masjid, zakat, puasa, haji, ihsan, amal saleh, menyayangi anak yatim. Hadis-hadis tersebut mengajak dan memerintahkan kepada anak-anak yang belajar di MDTA Al-Amin agar konsisten melaksanakan shalat dengan mengutamakan shalat berjamaah di masjid, memiliki sikap sosial yang baik kepada orang-orang yang miskin, anak-anak yatim dan mengajak mereka meningkatkan amal saleh dengan membiasakan mereka menyantuni anak yatim melalui uang sedekah dan uang infak yang mereka kumpulkan. ${ }^{20}$

c. Alquran

Alquran merupakan firman Allah yang diturunkan kepada Nabi Muhammad saw. dan membacanya adalah ibadah. ${ }^{21}$ Kewajiban seorang Muslim terhadap Alquran yaitu mempelajari, membaca, mengajarkan dan mengamalkan isinya. Di MDTA Al-Amin materi Alquran disatukan dengan tajwid dan tafsir, tujuannya agar anak-anak dapat membaca Quran dengan baik dan benar sesuai kaedah ilmu tajwid, mampu menghafal surat-surat dalam Quran sekaligus memahami tafsirnya. Surat-surat pendek yang dipelajari seperti surat al-“Alaq, Surat al-Qadr, al-Insyirah, adDhuha dan lain-lain. Surat-surat tersebut dapat dipergunakan oleh anak-anak di MDTA ketika shalat berjamaah. Mereka dilatih untuk menjadi imam dan makmum. Selain hafal mereka juga

\footnotetext{
${ }^{18}$ Studi dokumen, Buku Pelajaran Fikih di MDTA Al-Amin

${ }^{19}$ Nawir Yuslim, Ulumul Hadis (Jakarta: Mutiara Sumber Widya, 2001), h. 1.

${ }^{20}$ Studi dokumen, Buku Pelajaran Hadis di MDTA Al-Amin

${ }^{21}$ Manna Khalil al-Qattan, Mabahis fi 'Ulum al-Qur'an, terj. Mudzakir, Studi Ilmu-Ilmu Alquran (Jakarta: Litera Antar Nusa, 2001), h. 17.
}

Al-Madrasah: Jurnal Ilmiah Pendidikan Madrasah Ibtidaiyah Vol. 6, No. 1, Januari-Maret 2022 
Sofyan : Eksistensi Madrasah Diniyyah Takmiliyyah Awwaliyah (MDTA) Al-Amin Dalam Menanamkan Nilai-Nilai Pendidikan Islam di Kalangan Siswa Minoritas Muslim di Desa Lau Bekeri Kecamatan Kutalimbaru Deli Serdang

memahami makna yang terkandung di dalamnya, sehingga memudahkan untuk mengamalkannya sedikit demi sedikit dalam keseharian. ${ }^{22}$

d. Akhlak

Perkataan akhlak dalam Kamus Besar Bahasa Indonesia artinya watak, tabiat, budi pekerti. ${ }^{23}$ Kedudukan akhlak sangat penting dalam Islam sehingga harus ditanamkan kepada umat Islam. Di MDTA Al-Amin materi akhlak meliputi akhlak kepada sesama manusia seperti menjalin ukuhuwah islamiyah, dermawan, senang menolong orang lain, tawadhu (rendah hati), pemaaf, sedangkan akhlak kepada lingkungan seperti menjaga kebersihan, adab kepada hewan, kepada tumbuh-tumbuhan. Materi akhlak lainnya yaitu akhlak tidak terpuji (tercela) seperti perintah menjauhi akhlak tidak terpuji dengan menjauhi perilaku syirik, munafik, fasik, maksiat. Dengan materi ini anak-anak di MDTA Al-Amin diharapkan menjadi generasi muda yang memiliki akhlak terpuji, menjauhi perilaku tercela yang dilarang dalam Islam. ${ }^{24}$

e. Akidah

Pelajaran akidah menjadi materi inti yang harus tertanam dalam diri anak, karena seperti bangunan akidah adalah pondasinya. Jika pondasi bangunan tersebut tidak kuat maka akan mudah runtuh sebaliknya jika kuat dasarnya maka bangunan akan berdiri dengan kokoh. Materi akidah yang ditanamkan berkaitan dengan rukun iman yang enam yaitu beriman kepada Allah, Malaikat, Rasul, Kitab-kitab, hari kiamat, beriman kepada qadha dan qadar. Dengan aqidah yang terpatri kokoh di dalam sanubari diharapkan anak-anak di MDTA Al-Amin kuat dalam menghadapi tantangan hidup yang penuh dengan onak dan duri terkhusus menjalani kehidupan di tengah lingkungan yang berbeda akidah. ${ }^{25}$

f. Bahasa Arab

Bahasa Arab dipelajari anak-anak di MDTA Al-Amin karena bahasa Alquran ini dipelajari salah satunya sebagai kunci untuk membuka ilmu pengetahuan, karena sumber ilmu pengetahuan dari kitab-kitab yang berbahasa Arab. Dan bahasa Arab saat ini menjadi salah satu bahasa internasional sehingga setiap Muslim terpacu belajar bahasa ini dari tingkat dasar. Dengan diajarkannya bahasa Arab tentu menjadi motivasi bagi anak-anak di MDTA bisa berbahasa Arab, sebab materinya berkaitan dengan percakapan (muhadasah), membaca (qiraah), menyusun kata, kosa kata dan latihan-latihan. ${ }^{26}$

\footnotetext{
${ }^{22}$ Studi dokumen, Buku Pelajaran Alquran di MDTA Al-Amin

${ }^{23}$ Rosihon Anwar, Akhlak Tasawuf (Bandung: CV. Pustaka Setia, 2010), h. 11

${ }^{24}$ Studi dokumen, Pelajaran Akhlak di MDTA Syuhada

${ }^{25}$ Studi dokumen, Buku Pelajaran Akidah di MDTA Syuhada

${ }^{26}$ Studi dokumen, Buku Pelajaran bahasa Arab di MDTA Syuhada
} 
Sofyan : Eksistensi Madrasah Diniyyah Takmiliyyah Awwaliyah (MDTA) Al-Amin Dalam Menanamkan Nilai-Nilai Pendidikan Islam di Kalangan Siswa Minoritas Muslim di Desa Lau Bekeri Kecamatan Kutalimbaru Deli Serdang

g. Sejarah Islam

Anak-anak MDTA Al-Amin harus mengetahui sejarah Islam karena sumber ilmu pengetahuan dalam Islam selain Alquran, Hadis adalah sejarah. Sejarah masa lalu menjadi cerminan bagi umat sekarang. Kemajuan umat hari ini tidak terlepas dari sejarah masa silam. Di luar materi di atas terdapat beberapa kegiatan tambahan atau ekstra kurikuler seperti rihlah setiap akhir semester, latihan menulis kaligrafi, belajar pidato.

\section{Metode Dalam Menanamkan Nilai-Nilai Pendidikan Islam}

Metode dalam proses belajar mengajar diartikan dengan cara. Secara umum metode diartikan dengan cara melakukan suatu kegiatan atau cara melakukan pekerjaan dengan menggunakan fakta dan konsep-konsep secara sistematis. ${ }^{27}$

Untuk menanamkan nilai-nilai pendidikan Islam di MDTA Al-Amin dipergunakan beberapa metode, yaitu:

a. Metode ceramah

Metode klasik ini masih terus dipergunakan di dalam pendidikan Islam, karena menjadi satu-satunya metode yang ekonomis untuk menyampaikan informasi, efektif dalam mengatasi kelangkaan literatur atau rujukan yang sesuai dengan jangkauan pemahaman siswa. ${ }^{28}$

Motede ceramah menjadi metode yang banyak dipergunakan di MDTA Al-Amin, materimateri yang menggunakan ceramah seperti materi Hadis, tarikh (sejarah), akidah, atau kolaborasi antara ceramah dengan demonstrasi disesuaikan dengan materi yang diajarkan. Kelebihan dari metode ini guru dengan mudah mempersiapkan, menerangkan dan melaksanakan pelajaran dengan baik, dapat diikuti siswa dengan jumlah yang besar, mudah menguasai dan mengorganisasi kelas. Kelemahannya terlalu lama dan membosankan. ${ }^{29}$

b. Metode demonstrasi

Penerapan metode demonstrasi di MDTA Al-Amin dilaksanakan pada saat ustaz-ustazah menjelaskan materi tentang shalat jenazah, wudhu, tayamum, shalat fardhu dimana materi pelajaran disajikan secara lisan kemudian guru memperagakan langsung kepada siswa proses atau tata cara berwudhu, tayamum, maupun shalat. Adapun siswa menyaksikan dan menerima materi secara berkesan dan mendalam sehingga mereka dapat memahami secara baik dan sempurna. ${ }^{30}$

${ }^{27}$ Muhibbinsyah, Psikologi Pendidikan (Bandung: Remaja Rosdakarya, 2010), h. 198.

${ }^{28}$ Ibid., h. 200.

${ }^{29}$ Metode demonstrasi adalah cara penyajian pelajaran dengan mempertunjukkan atau memperagakan kepada siswa suatu proses, situasi atau benda tertentu yang sedang dipelajari baik sebenarnya atau pun tiruan yang disertai dengan penjelasan secara lisan. Syaiful Bahri Djamarah dan Aswan Zein, Strategi Belajar Mengajar (Jakarta: PT. Rineka Cipta, 2010), h. 96.

${ }^{30}$ Ibid., h. 90.

Al-Madrasah: Jurnal Ilmiah Pendidikan Madrasah Ibtidaiyah

Vol. 6, No. 1, Januari-Maret 2022 
Sofyan : Eksistensi Madrasah Diniyyah Takmiliyyah Awwaliyah (MDTA) Al-Amin Dalam Menanamkan Nilai-Nilai Pendidikan Islam di Kalangan Siswa Minoritas Muslim di Desa Lau Bekeri Kecamatan Kutalimbaru Deli Serdang

Selain dapat memahami pelajaran dengan baik kelebihan metode ini proses pengajaran menjadi lebih menarik karena siswa dimotivasi untuk dapat mengamati dan menyesuaikan antara teori dengan kenyataan bahkan dia dapat melakukannya sendiri. Kekurangan dari metode ini membutuhkan keterampilan secara khusus dari para guru jika tidak metode ini tidak dapat dilakukan secara efektif, memerlukan perencanaan dan persiapan yang matang dan memadai dengan waktu yang sedikit panjang. ${ }^{31}$

c. Metode Latihan/Training

Metode ini dipergunakan untuk mengajari, menanamkan serta memelihara kebiasaankebiasaan yang baik kepada siswa dengan cara melafalkan huruf, kata-kata ataupun kalimat seperti membaca Alquran beserta dengan ilmu tajwid, tafsir, belajar bahasa Arab dan praktek shalat. Kelebihan metode ini siswa terbiasa untuk membaca Quran dengan benar, mampu berbahasa Arab dengan baik serta dapat melakukan gerakan-gerakan seperti gerakan shalat, berwudhu atau ibadah lain yang kompleks menjadi lebih otomatis dan mudah. Kekurangannya terkadang menimbulkan kebosanan karena dilakukan secara berulang-ulang, melahirkan kebiasaan yang kaku dan meng-hambat bakat serta inisiatif siswa. ${ }^{32}$

\section{Faktor Pendukung Eksistensi MDTA Al-Amin}

Keberadaan MDTA Al-Amin sejak awal berdiri sampai saat ini senantiasa mendapat dukungan moral dan materil baik dari tokoh-tokoh agama, jamaah masjid serta masyarakat Muslim di Desa Lau Bekeri. Dukungan yang kuat dan jalinan ukuhuwah islamiyah yang baik di antara warga masih dominan dari dahulu sampai saat ini. Hal ini menjadi modal utama tetap eksisnya madrasah ini dari dahulu sampai sekarang terkhusus dalam memberikan kontribusi positif meningkatkan pemahaman siswa serta memajukan pendidikan Islam di Desa Lau Bekeri.

Dukungan lain datang dari Bupati Kepala Daerah Tingkat II Deli Serdang melalui Kementrian Agama Kabupaten Deli Serdang yang berpartisipasi dan turut memberikan perhatian terhadap kemajuan pendidikan di wilayahnya. Para ustaz dan ustazah yang mengajar di MDTA Al-Amin diberikan insentif tambahan Rp 1.200.000. walaupun tidak banyak tetapi membantu untuk melengkapi kebutuhan hidupnya.

\section{Faktor Penghambat dalam Menanamkan Nilai-Nilai Pendidikan Islam}

Penanaman nilai-nilai pendidikan Islam di MDTA Al-Amin tidak berjalan mulus. Terdapat beberapa hambatan dan tantangan baik secara internal maupun eksternal. Secara umum tantangan tersebut meliputi;

\footnotetext{
${ }^{31}$ Ibid., h. 91.

${ }^{32}$ Ibid., h. 96
}

Al-Madrasah: Jurnal Ilmiah Pendidikan Madrasah Ibtidaiyah

Vol. 6, No. 1, Januari-Maret 2022 
Sofyan : Eksistensi Madrasah Diniyyah Takmiliyyah Awwaliyah (MDTA) Al-Amin Dalam Menanamkan Nilai-Nilai Pendidikan Islam di Kalangan Siswa Minoritas Muslim di Desa Lau Bekeri Kecamatan Kutalimbaru Deli Serdang

a) Kemajuan teknologi. Masyarakat Muslim yang ada di perkotaan maupun mereka yang tinggal di pedesaan banyak yang terkontaminasi dengan canggihnya teknologi saat ini, sehingga tidak mampu mengontrol diri untuk tidak melihat media sosial. Sehingga setiap waktu mereka selalu berinteraksi dengan media sosial, tidak sedikit yang menghabiskan waktunya untuk bermain game dan berbagai permainan lainnya. Saat ini lebih kurang 200 juta masyarakat Indonesia sekarang sebagai pengguna aktif internet dan menghabiskan waktunya selama 7-8 jam. Tentunya hal ini menjadi hambatan terbesar dan paling berat yang dihadapi umat Islam;

b) Kebodohan dan kurangnya pemahaman orang tua untuk mendidik, membekali anakanak mereka dengan ilmu agama. Mereka lebih cenderung dan memotivasi penuh anak-anak mereka untuk belajar di sekolah-sekolah umum. Bagi mereka pendidikan agama nomor dua, yang paling utama adalah anak-anak mereka dapat duduk di bangku sekolah yang berbasis umum supaya mereka mudah mencari lapangan pekerjaan dengan mengabaikan pendidikan agama;

c) Miliu atau lingkungan. Tidak dipungkiri jika lingkungan masyarakatnya religius, taat menjalankan perintah Tuhan akan mempengaruhi kehidupan masyarakat sekitarnya. Keluarga yang religius, menjalankan perintah agama akan membekali anak-anak mereka dengan memasukkan mereka ke madrasah-madrasah. Mereka berharap ilmu agama tersebut modal dan bekal bagi anak untuk menjadi pribadi yang berkarakter dan anak saleh yang berbakti kepada agama, nusa dan bangsa. Sebaliknya, masyarakat yang jauh kehidupannya dari nilai-nilai agama akan cenderung tidak memperdulikan pendidikan agama anaknya. Bagi masyarakat Muslim yang berada di Desa Lau Bekeri mendidik anak di MDTA Al-Amin tidak lain untuk membentengi diri dengan akidah dan ilmu agama agar anak dapat tumbuh dan berkembang menjadi pribadi yang kuat iman dari pengaruh lingkungan yang mayoritas bukan beragama Islam.

Ketiga faktor di atas mempengaruhi motivasi orang tua untuk mendidik dan membekali ilmu agama anaknya. Bagi orang tua yang kuat pemahaman agama akan memasukkan anak-anak mereka ke madrasah. Pagi hari anaknya belajar di sekolah umum kemudian pada waktu sore mereka menyerahkan anak-anaknya belajar ilmu agama di madrasah yaitu MDTA Al-Amin. Pemikiran mereka sedikit pun tidak terpengaruh dengan teknologi dan lingkungan yang minoritas Muslim, sehingga tetap memiliki motivasi kuat untuk memasukkan anak-anak mereka belajar agama Islam.

\title{
KESIMPULAN
}

Masjid Al-Amin menjadi pusat peribadahan masyarakat di Desa Lau Bekeri Kutalimbaru dan sekitarnya. Dengan tanahnya yang luas Badan Kenaziran Masjid (BKM) Al-Amin mendirikan

\author{
Al-Madrasah: Jurnal Ilmiah Pendidikan Madrasah Ibtidaiyah \\ Vol. 6, No. 1, Januari-Maret 2022
}


Sofyan : Eksistensi Madrasah Diniyyah Takmiliyyah Awwaliyah (MDTA) Al-Amin Dalam Menanamkan Nilai-Nilai Pendidikan Islam di Kalangan Siswa Minoritas Muslim di Desa Lau Bekeri Kecamatan Kutalimbaru Deli Serdang

lembaga pendidikan tingkat dasar yaitu MDTA Al-Amin untuk menanamkan nilai-nilai pendidikan Islam, mencerdaskan generasi muda minoritas Muslim menjadi individu yang siap untuk menghadapi globalisasi serta dapat hidup di tengah-tengah lingkungan yang non Muslim. Pendidikan Alquran, Hadis, akhlak, Bahasa Arab, sejarah, fikih, serta akidah menjadi materi yang diajarkan dan ditanamkan kepada peserta didik. Metode yang dipergunakan dalam menanamkan nilai-nilai pendidikan pun bervariasi, dari metode ceramah, demonstrasi maupun metode training. Dengan dukungan dari masyarakat, tokoh agama maupun Pemerintah Kabupaten Deli Serdang sejatinya semakin mengokohkan eksistensi MDTA Al-Amin dalam berkontribusi memajukan pendidikan Islam di Desa Lau Bekeri.

\section{DAFTAR PUSTAKA}

Al-Syaibany, 1979. Omar Mohammad al-Toumy. Falsafah at-Tarbiyah al-Islamiyah, terj. Hasan Langgulung, Falsafah Pendidikan Islam. Jakarta: Bulan Bintang.

Anwar, Rosihon. 2010. Akhlak Tasawuf. Bandung: CV. Pustaka Setia.

Al-Qattan, Manna Khalil. 2001. Mabahis fi 'Ulum al-Qur'an, terj. Mudzakir, Studi Ilmu-Ilmu Alquran. Jakarta: Litera Antar Nusa.

Buku Silabus dan Kurikulum Pendidikan dan Pengajaran di MDTA Syuhada.

Djamarah, Syaiful Bahri dan Zein, Aswan. 2010. Strategi Belajar Mengajar. Jakarta: PT. Rineka Cipta.

Jalaluddin, 2012. Psikologi Agama. Jakarta: Rajawali Pers.

Lubis, Lahmuddin dan Muchtar, Elfiah. 2013. Pendidikan Agama Dalam perspektif Islam, Kristen dan Budha. Bandung: Citapustaka Media Perintis.

Muhibbinsyah, 2010. Psikologi Pendidikan. Bandung: Remaja Rosdakarya.

Poerwardarminta, 1976. W.J.S. Kamus Umum Bahasa Indonesia. Jakarta: Balai Pustaka.

Suparta, 2006. Undang-Undang dan Peraturan Pemerintah RI Tentang Pendidikan. Jakarta: Direktorat Jenderal Pendidikan Islam Departemen Agama RI.

Studi dokumen, Buku Pelajaran Fikih di MDTA Syuhada

Studi dokumen, Buku Pelajaran Hadis di MDTA Syuhada

Studi dokumen, Buku Pelajaran Alquran di MDTA Syuhada

Wawancara dengan Ustaz Abidin Saragih, Kepala Sekolah MDTA Syuhada

Yuslim. Nawir, 2001. Ulumul Hadis. Jakarta: Mutiara Sumber Widya.

Al-Madrasah: Jurnal Ilmiah Pendidikan Madrasah Ibtidaiyah

Vol. 6, No. 1, Januari-Maret 2022 